\title{
Antidiarrhoeal property of the hydroethanolic extract of the flowering tops of Anthocephalus cadamba
}

\author{
M. Ashraful Alam, ${ }^{1}$ Raushanara Akter, ${ }^{1}$ Nusrat Subhan, ${ }^{2}$ M. Mostafizur Rahman, ${ }^{1}$ Muntasir \\ M. Majumder, ${ }^{1}$ Lutfun Nahar, ${ }^{3}$ Satyajit D. Sarker*,3
}

${ }^{1}$ Department of Pharmacy, Stamford University, Dhaka, Bangladesh,

${ }^{2}$ Department of Pharmacy, Northern University, Dhaka, Bangladesh,

${ }^{3}$ Department of Pharmacy and Pharmaceutical Sciences School of Biomedical Sciences, University of

Ulster, Cromore Road, Coleraine BT52 1SA,Co. Londonderry, Northern Ireland, UK

\begin{abstract}
RESUMO: "Propriedade antidiarréica do extrato hidroetanólico dos topos floridos de Anthocephalus cadamba". A propriedade antidiarréica do extrato hidroetanólico dos topos floridos de Anthocephalus cadamba foi avaliada em animais experimentais. O extrato hidroetanólico seco (250-500 mg/kg massa corpórea, v.o.) exibiu uma diminuição dose-dependente do número total de excrementos na diarréia induzida por óleo de castor em camundongos. O extrato também causou uma redução significativa $(p<0.01)$ e dose-dependente do acúmulo de fluidos intestinais e do trânsito gastrointestinal de $64,59 \%$ e $71,19 \%$ nas doses de 250 e $500 \mathrm{mg} / \mathrm{kg}$. As taxas de redução foram de $37,85 \%$ e $74,91 \%$, respectivamente, com o grupo controle e da droga padrão.
\end{abstract}

Unitermos: Anthocephalus cadamba, Rubiaceae, antidiarréica, óleo de castor, trânsito gastrointestinal.

\begin{abstract}
The antidiarrhoeal property of the hydroethanolic extract of the flowering tops of Anthocephalus cadamba was assessed on experimental animals. The dry hydroethanolic extract (250-500 $\mathrm{mg} / \mathrm{kg}$ body mass, p.o.) exhibited a dose-dependent decrease in the total number of faecal droppings in castor oil-induced diarrhoea in mice. The extract also produced a significant $(p<0.01)$ and dose-dependent reduction in intestinal fluids accumulation and in the gastrointestinal transit from $64.59 \%$ and $71.19 \%$ at doses of 250 and $500 \mathrm{mg} / \mathrm{kg}$. The reduction rates were $37.85 \%$ and $74.91 \%$, respectively, with the control and standard drug group.
\end{abstract}

Keywords: Anthocephaluscadamba, Rubiaceae,Antidiarrhoeal,Castoroil, Gastrointestinaltransit.

\section{INTRODUCTION}

Diarrhoea is one of the major causes of mortality and morbidity in children, especially under the age of 5 years, in Bangladesh and other third world countries. Diarrhoea takes a heavy toll in Bangladesh, which is criss-crossed by waterways and routinely affected by floods, cyclones and, recently, droughts. Each year, some 20 million children suffer an average of 3.5 episodes of diarrhoea. After acute respiratory infections, it is the second leading cause of death among children (Alam et al., 2001). While in Bangladesh, about $17 \%$ of all children admitted to the paediatrics ward die of diarrhoea, about 5-8 million deaths each year in infants and children below 5 years old are caused by diarrhoea worldwide (Fauci et al., 1998). The need for newer, more effective, and most importantly, cheaper antidiarrhoeal drugs has become a paramount issue to tackle this present situation. A number of Bangladeshi medicinal plants have been used by traditional healers to treat diarrhoea and related complications. However, the effectiveness of many of these antidiarrhoeal traditional medicines has not been scientifically evaluated.

Anthocephalus cadamba (Roxb.) Miq. [Syn. Neolamarckia cadamba (Roxb.) Bosser] of the family Rubiaceae is widely distributed throughout Bangladesh, Nepal, India, Myanmar, Sri Lanka, the Philippines, Indonesia, and Papua New Guinea (Banerji, 1977; 1978; Sahu et al., 2000; GRIN Databases, 2007). Various parts of this plant have traditionally been used as an antidiuretic, in the treatment of fever, anaemia and tumour, and for the improvement of semen quality (Umachigi et al., 2007; Dr. Duke's Phytochemical and Ethnobotanical Databases, 2007). While previous bioactivity studies on this plant revealed its antimicrobial, antioxidant and wound healing properties, antimalarial and antihepatotoxic activities (Umachigi et al., 2007), the phytochemical investigations resulted in the isolation of indole alkaloids, secoiridoids, triterpenes and saponins from this plant (Banerji, 1977; 1978; Brown and Chapple, 1976; Kitagawa et al., 1996; Sahu et al., 1999; 2000).

In continuation of our phytochemical and pharmacological screening of Bangladeshi medicinal 
plants (Uddin et al., 2005, 2007a-c; Saha et al., 2007; Datta et al., 2007), we now report on the antidiarrhoeal property of Anthocephalus cadamba flowering tops.

\section{MATERIAL AND METHODS}

\section{Plant material}

The flowering tops of Anthocephalus cadamba (Roxb.) Miq. were collected from Siddeswari campus, Stamford University, Bangladesh in June 2007, and identified by Professor Abdul Ghani (Stamford University, Dhaka, Bangladesh), and a voucher specimen (SU-MAA-2007-2) for this collection has been retained in the Pharmacognosy Laboratory, Stamford University, Dhaka, Bangladesh.

\section{Extraction}

Shade-dried and powdered flowering tops of $A$. cadamba $(200 \mathrm{~g})$ were Soxhlet-extracted using $70 \%$ aqueous ethanol. The extract was concentrated by evaporation under reduced pressure at $40{ }^{\circ} \mathrm{C}$ using a Buchi rotary evaporator to yield a concentrate of reddish black extract (yield appx. 6.32\%).

\section{Drugs and chemicals}

Atropine sulphate and loperamide (standard reference antidiarrhoeal drugs), castor oil (laxative agent), normal saline solution $(0.9 \% \mathrm{NaCl})$, charcoal meal $(10 \%$ activated charcoal in $5 \%$ tragcanth) and vehicle (distilled water) were used.

\section{Animals}

Swiss albino mice weighing $20-25 \mathrm{~g}$ of both sexes were obtained from the Animal House of the International Centre for Diarrhoeal Disease and Research, Bangladesh (ICDDR, B). The animals were housed under standard laboratory conditions (relative humidity $55-65 \%$, r.t. $23.0 \pm 2.0^{\circ} \mathrm{C}$ and $12 \mathrm{~h}$ light:dark cycle). The animals were fed with standard diet and water ad libitum.

\section{Effect of extract on castor oil-induced diarrhoea}

The method described by Uddin et al. (2005) and Awouters et al. (1978) was adopted to study the effect of the $A$. cadamba extract on castor oil-induced diarrhoea. Mice were weighed and grouped into 4 groups $(\mathrm{n}=5)$. Group 1 received distilled water, group 2 and 3 were administered 250 and $500 \mathrm{mg} / \mathrm{kg}$ extract orally while group 4 received loperamide $(5 \mathrm{mg} / \mathrm{kg})$ orally. Each animal was then given $0.5 \mathrm{~mL}$ of castor oil orally after 30 min of treatment and placed in transparent cages to observe for consistency of faecal matter and frequency of defecation for $3 \mathrm{~h}$. Faeces were collected with an absorbent sheet of paper placed beneath the transparent cages (Mukherjee et al., 1998). The wet faeces were read at the end of the experiment by lifting up the upper part of the cage containing the sheet of paper and animals. The percent (\%) inhibition of defecation was measured using the following formula.

$\%$ Inhibition of defecation $=[(\mathrm{A}-\mathrm{B}) / \mathrm{A}] \mathrm{x} 100$

$A=$ Mean number of defecation caused by castor oil

$\mathrm{B}=$ Mean number of defecation caused by drug or extract

Effect of extract on castor oil-induced intestinal fluid accumulation

This was determined as described by Robert et al. (1976) and Dicarlo et al. (1994). Briefly, the mice were fasted for $24 \mathrm{~h}$ but allowed free access to water. The mice were randomised and placed in 3 cages of 4 rats per cage each. Group 1 was administered distilled water, while groups 2 and 3 were pre-treated with 25 and $50 \mathrm{mg} / \mathrm{kg}$ of the extract, respectively. After $30 \mathrm{~min}$, each rat was administered $2 \mathrm{~mL}$ of castor oil. The rats were anaesthetised $30 \mathrm{~min}$ later by inhalation of chloroform. The small intestine from the pylorus to caecum was dissected out and its content expelled into a measuring cylinder to measure the volume of the fluid.

\section{Study of small intestinal transit}

This was carried out according to the method outlined by Uddin et al. (2005) and Mujumdar (1998) using charcoal meal as a diet marker. The mice were divided into 4 groups of 6 animals each. The first group (the control group) was orally administered the vehicle ( $0.5 \%$ Tween 80 in distilled water). The second and third groups orally received CGAE, $375 \mathrm{mg} / \mathrm{kg}$ and $750 \mathrm{mg} / \mathrm{kg}$ body weight, respectively. The fourth group also orally received the standard drug, atropine sulphate $(5 \mathrm{mg} / \mathrm{kg}$ body weight). Thirty minutes after administration, each animal was given $1 \mathrm{~mL}$ of charcoal meal orally $(10 \%$ activated charcoal in 5\% gum acacia). After $30 \mathrm{~min}$, each animal was sacrificed and the distance covered by the charcoal meal in the intestine, from the pylorus to the caecum was measured and expressed as a percentage of distance moved.

\section{Statistical analysis}

Experimental values were expressed as Mean \pm SEM. Independent Sample t-test was carried out for statistical comparison. Statistical significance was considered to be indicated by a $p$ value $<0.05$ in all cases.

\section{RESULTS AND DISCUSSION}


In the castor oil-induced diarrhoea experiment, the mice group that did not receive the plant extract showed typical diarrhoeal signs and symptoms such as watery and frequent defecation. The hydroethanolic extract of A. cadamba produced a notable antidiarrhoeal effect in mice (Table 1). Both doses of the extract significantly decreased $(p<0.05)$ the total number of wet faeces produced by administration of castor oil (7.6 \pm 0.570 at the dose of $250 \mathrm{mg} / \mathrm{kg}$ and $5.2 \pm 0.651$ at the dose of $500 \mathrm{mg} / \mathrm{kg}$ ) as compared to the castor oiltreated control group $(13.2 \pm 0.651)$ at third hour of observation. The percentage of inhibition of castor oilinduced diarrhoea in the extract-treated mice was 42.42 and $62.62 \%$, respectively, at the doses of 250 and 500 $\mathrm{mg} / \mathrm{kg}$. The effect of the extract was similar to that of the standard drug, loperamide $(3 \mathrm{mg} / \mathrm{kg})$, which produced an inhibition of $63.63 \%$ (Table 1 ).

The average volume of faeces in the control group was $1.108 \pm 0.072 \mathrm{~mL}$. Treatment with both doses of the extract significantly reduced $(\mathrm{p}<0.05)$ the volume of faeces to $0.074 \pm 0.037 \mathrm{~mL}$ and $0.082 \pm 0.041$ $\mathrm{mL}$, respectively, at the doses of 250 and $500 \mathrm{mg} / \mathrm{kg}$
(Table 2).

The administration of the extract also slowed down the propulsion of charcoal meal through the gastrointestinal tract when compared to the castor oiltreated mice. The percentage inhibition of intestinal length travelled by charcoal meal in the extract-pretreated $(250$ and $500 \mathrm{mg} / \mathrm{kg})$ and castor oil-treated mice was $64.590 \pm 1.543 ; 71.190 \pm 1.264$ and $37.854 \pm 2.539$, respectively. Atropine on its part produced a marked decrease in the propulsive movement and the intestinal length travelled by charcoal meal and the percentage inhibition of transit was $74.916 \pm 1.028$ (Table 3).

The castor oil test has been used extensively to screen and evaluate antidiarrhoeal properties of drugs in mice. Within $1 \mathrm{~h}$ of oral administration of the oil, the animals begin to evacuate watery stools (Awouters et al., 1975; Santos et al., 2007). Castor oil causes diarrhoea due to its active metabolite, ricinolic acid (Ammon and Thomas, 1974; Watson and Gordon, 1962), which stimulates peristaltic activity in the small intestine, leading to changes in the electrolyte permeability of the intestinal mucosa. Its action also stimulates the release

Table 1. Effect of the hydroethanolic extract of A. cadamba on castor oil-induced diarrhoea in mice.

\begin{tabular}{|c|c|c|c|c|c|c|}
\hline \multirow[t]{2}{*}{ Group } & \multirow[t]{2}{*}{ Treatment } & \multirow{2}{*}{$\begin{array}{l}\text { Latent time } \\
\quad(\min )\end{array}$} & \multicolumn{2}{|c|}{$\begin{array}{c}\text { Number of } \\
\text { faeces at first hour }\end{array}$} & \multirow{2}{*}{$\begin{array}{l}\text { Number of } \\
\text { watery faeces at } \\
\text { second hour }\end{array}$} & \multirow{2}{*}{$\begin{array}{c}\text { Number of } \\
\text { watery faeces } \\
\text { at third hour }\end{array}$} \\
\hline & & & Hard stool & Watery stool & & \\
\hline Control & $\begin{array}{l}\text { Castor oil } \\
10 \mathrm{~mL} / \mathrm{kg}\end{array}$ & $15.9 \pm 0.798$ & $9.6 \pm 0.974$ & $2.6 \pm 0.447$ & $11.2 \pm 0.961$ & $13.2 \pm 0.651$ \\
\hline Standard drug & $\begin{array}{l}\text { Castor oil }+ \\
\text { Loperamide }\end{array}$ & $\begin{array}{c}37.8 \pm 1.781 \\
* *\end{array}$ & \multicolumn{2}{|c|}{$(\%$ inhibition $63.93 \%)$} & $\begin{array}{c}5.4 \pm 0.570 \\
(51.71 \%) \\
* *\end{array}$ & $\begin{array}{c}4.8 \pm 0.418 \\
(63.63 \%) \\
* *\end{array}$ \\
\hline Test group I & $\begin{array}{c}\text { Castor oil }+ \\
\text { crude extract } 250 \\
\mathrm{mg} / \mathrm{kg}\end{array}$ & $\begin{aligned} 25.6 & \pm 0.647 \\
& * *\end{aligned}$ & \multicolumn{2}{|c|}{$\underset{* *}{(\% \text { inhibition } 36.065 \%)}$} & $\begin{array}{c}9.2 \pm 0.741 \\
(17.85 \%) \\
* *\end{array}$ & $\begin{array}{c}7.6 \pm 0.570 \\
(42.42 \%) \\
* *\end{array}$ \\
\hline Test group II & $\begin{array}{c}\text { Castor oil }+ \\
\text { crude extract } 500 \\
\mathrm{mg} / \mathrm{kg}\end{array}$ & $\begin{array}{l}30.44 \pm 0.890 \\
* *\end{array}$ & \multicolumn{2}{|c|}{$\begin{array}{c}(\% \text { inhibition } 56.72 \%) \\
* *\end{array}$} & $\begin{array}{c}5.6 \pm 0.570 \\
(50.00 \%) \\
* *\end{array}$ & $\begin{array}{c}5.2 \pm 0.651 \\
(60.60 \%) \\
* *\end{array}$ \\
\hline
\end{tabular}

Effect of the extract on castor oil-induced diarrhoea in mice. Extracts were administered per orally 45 minutes before castor oil administration. Values are expressed as mean \pm SEM, $n=5 ; * *$ Significant relative to control $(\mathrm{p}<0.05)$.

Table 2. Effect of the hydroethanolic extract of A. cadamba on castor oil-induced fluid accumulation in mice.

\begin{tabular}{lcc}
\hline Group & Treatment & Volume of fluid accumulated in the intestine (mL) \\
\hline Control & Castor oil $10 \mathrm{~mL} / \mathrm{kg}$ & $1.108 \pm 0.072$ \\
Standard drug & Castor oil + Loperamide & $0.274 \pm 0.017$ \\
Test group I & Castor oil + crude extract $250 \mathrm{mg} / \mathrm{kg}$ & $0.074 \pm 0.037$ \\
Test group II & Castor oil + crude extract $500 \mathrm{mg} / \mathrm{kg}$ & $0.082 \pm 0.041$ \\
\hline
\end{tabular}

Effect of the extract on castor oil-induced fluid accumulation in mice. Extracts were administered per orally 45 min before castor oil administration. Values are expressed as mean $\pm \mathrm{SEM}, \mathrm{n}=5 ; * *$ Significant relative to control $(\mathrm{p}<0.05)$.

Table 3. Effect of the hydroethanolic extract of $A$. cadamba on gastrointestinal transit fed with charcoal meal in mice.

\begin{tabular}{|c|c|c|c|c|c|}
\hline Group & Treatment & $\begin{array}{l}\text { Length of the } \\
\text { Intestine }(\mathrm{cm})\end{array}$ & $\begin{array}{c}\text { Length of intestinal } \\
\text { transit }(\mathrm{cm})\end{array}$ & $\begin{array}{l}\% \text { inhibition of } \\
\text { transit }\end{array}$ & \\
\hline Control & Distilled water + Charcoal meal & $78.186 \pm 2.755$ & $48.6 \pm 2.706$ & $37.854 \pm 2.539$ & \\
\hline Standard drug & Atropine sulphate + Charcoal meal & $70.168 \pm 1.897 * *$ & $17.6 \pm 0.836^{* *}$ & $74.916 \pm 1.028 * *$ & \\
\hline Test group I & Charcoal meal + crude extract $250 \mathrm{~g} / \mathrm{kg}$ & $80.124 \pm 1.934 * *$ & $28.4 \pm 1.604 * *$ & $64.590 \pm 1.543^{* *}$ & \\
\hline \multirow[t]{2}{*}{ Test group II } & Charcoal meal + crude extract $500 \mathrm{~g} / \mathrm{kg}$ & $79.16 \pm 0.182$ & $22.8 \pm 0.961 * *$ & $71.190 \pm 1.264 * *$ & \\
\hline & & & & $\begin{array}{r}\text { Rev. Bras. Farmacogn. } \\
\text { Braz J. Pharmacogn. } \\
\text { 18(2): Abr./Jun. } 2008\end{array}$ & 157 \\
\hline
\end{tabular}


of endogenous prostaglandin (Galvez et al., 1993). Loperamide, apart from regulating the gastrointestinal tract, is also reported to slow down transit in the small intestine, reduce colon flow rate, and consequently any effect on colonic motility (Theoderau et al., 1991; Salgado et al., 2005).

In this study, the hydroethanolic extract of $A$. cadamba displayed a significant and dose-dependent antidiarrhoeal property. The results were similar to that of the standard drug loperamide $(3 \mathrm{mg} / \mathrm{kg}$ ) with regard to the severity of diarrhoea. The extract significantly reduced intestinal transit as observed by the decrease in intestinal motility of charcoal meal, and also led to a marked reduction in the volume of the intestinal contents.

The antidiarrhoeal property of the hydroalcoholic extract of $A$. cadamba found in the present study could be owing to the presence of indole alkaloids, secoiridoids, triterpenes and saponins in this plant. Previous studies showed that antidysenteric and antidiarrhoeal properties of medicinal plants were mostly due to tannins, alkaloids, saponins, flavonoids, sterol and triterpenes (Galvez et al., 1991, 1993; Longanga et al., 2000).

The results obtained in this study established the antidiarrhoeal property of the hydroethanolic extract of the flowers tops of $A$. cadamba.

\section{ACKNOWLEDGMENTS}

The authors would like to thank Professor Abdul Ghani (Stamford University) for taxonomical identification of the plant sample, and Stamford University, Bangladesh for providing necessary fundings and logistics.

\section{REFERENCES}

Alam NH, Faruque AS, Dewan N, Sarker SA, Fuchs GJ 2001. Characteristics of children hospitalized with severe dehydration and persistent diarrhoea in Bangladesh. J Health Popul Nutr 19: 18-24.

Ammon PJ, Thomas PS 1974. Effects of oleic and recinoleic acids net jejunal water and electrolyte movement $J$ Clin Invest 53: 374-379.

Awouters F, Neimegeers CJE, Lenaert FM, Janssen PAJ 1978. Delay of castor oil diarrhoea in rats; A new way to evaluate inhibitors of prostaglandin's biosynthesis. $J$ Pharm Pharmacol 30: 41-45.

Awouters F, Niemegeers CJE, Kuyps KJ, Janseen PAJ 1975. Loperamide antagonism of castor oil - induced diarrhoea in rats: A quantitative study. Arch Int Phar 217: 29-37.

Banerji N 1978. Structure of 2 new saponins from stem bark of Anthocephalus cadamba MIQ. J Indian Chem Soc 55: 275-278.

Banerji N 1977. New saponins from stem bark of Anthocephalus cadamba MIQ. Indian J Chem B 15: 654-655.

Brown RT, Chapple CL 1976. Anthocephalus alkaloids: cadamine and isocadamine. Tetrahedron Lett 19: 629-630.

Datta BK, Nahar L, Rahman MM, Gray AI, Auzi AA, Sarker SD 2007. Polygosumic acid, a new cadinane sesquiterpene, from Polygonum viscosum inhibits the growth of drug-resistant Escherichia coli and Staphylococcus aureus (MRSA) in vitro. J Nat Med 61: 391-396.

Dicarlo GD, Mascolo N, Izzo AA, Capasso F 1994. Effect of quereetine on the gastrointestinal tract in rats and mice. Phytother Res 8: 42-45.

Dr. Duke's Phytochemical and Ethnobotanical Database 2007. ARS, National Genetic Resources Program. Germplasm Resources Information Network (GRIN), National Germplasm Resources Laboratory, Beltsville, Maryland. Available on-line at: http:// www.ars-grin.gov/cgi-bin/duke/ethnobot.pl

Fauci AS, Bravnwold E, Isselpacker K, Wilson JD, Kasper DL, Hauser SL, Longo DL 1998. Harrison's Principles of Internal Medicine. New York, McGraw Hill Company, vol 1, pp. 236-242.

Galvez J, Zarzuelo A, Crespo ME 1991. Antidiarrhoeic activity of Scleroarya birrea bark extract and its active tannin constituent in rats. Phytother Res 5: 276-278.

Galvez J, Zarzuelo A, Crespo ME, Lorente MD, Ocete MA, Jimenez J 1993. Antidiarrhoeic activity of Euphorbia hirta extract and isolation of an active flavonoid constituent. Planta Medi 59: 333-336.

GRIN Taxinomy Databases 2007. USDA, ARS, National Genetic Resources Program. Germplasm Resources Information Network - (GRIN), National Germplasm Resources Laboratory, Beltsville, Maryland. Available on-line at: http://www.ars-grin.gov/cgibin/npgs/html/taxon.pl?3575

Kitagawa I, Wei H, Nagao S, Mahmud T, Hori K, Kobayashi M, Uji T, Shibuya H 1996. Indonesian medicinal plants. XIV. Characterisation of 3'-O-caffeoylsweroside, a new secoiridoid glucoside, and kelampayosides A and B, two new phenolic apiglucosides from the bark of Anthocephalus chinensis (Rubiaceae). Chem Pharm Bull 44: 1162-1167.

Longanga OA, Vercruysse A, Foriers A 2000. Contribution to the ethnobotanical, phytochemical and pharmacological studies of traditionally used medicinal plant in the treatment of dysentery and diarrhoea in Lomela area, Democratic Republic of Congo (DRC). J Ethnopharmacol 71: 411-423.

Mujumdar AM 1998. Antidiarrhoeal activity of Azadiachta indica leaf extract. Indian Drugs 35: 417-420.

Mukherjee PK, Saha K, Murugesan T, Mandal SC, Pal M, Saha BP 1998. Screening of antidirrhoeal profile of some plant extracts of a specific region of West Bengal. Indian J Ethnopharmacol 60: 85-89.

Robert A, Nezarmis JE, Lancaster C, Henchar AI, Kleppre MS 1976. Enteropooling Assay: A test for diarrhoea produced by prostaglandins. Prostaglandins 11: 809-814.

Saha A, Masud MA, Bachar SC, Kundu JK, Nahar L, Datta BK, Sarker SD 2007. Analgesic and anti-inflammatory activities of the extracts of Phyllanthus reticulatus in mice model. Pharm Biol 45: 355-359.

Sahu NP, Koike K, Jia ZH, Banerjee S, Mandal NB, Nikaido $\mathrm{T}$ 2000. Triterpene glycosides from the bark of 
Anthocephalus cadamba. J Chem Res $S$ 22-23.

Sahu NP, Koike K, Jia ZH, Achari B, Banerjee S, Nikaido T 1999. Structure of two novrel isomeriv triterpene saponins from Anthocephalus cadamba. Magn Reson Chem 37: 837-742.

Salgado HRN, Roncari AFF, Moreira RRD 2005. Antidiarrhoeal effects of Mikania glomerata Spreng. (Asteraceae) leaf extract in mice. Rev Bras Farmacogn 15: 205-208.

Santos VL, Costa VBM, Agra MF, Silva BA, Batista LM 2007. Pharmacological studies of ethanolic extracts of Maytenus rigida Mart (Celastraceae) in animal models. Rev Bras Farmacogn 17: 336-342.

Theoderau V, Fioramont J, Hachet T, Bueno L 1991. Absorptive and motor components of anti-diarrhoeal action of loperamide: an in vivo study in pigs, Gut 32: 1355-1359.

Uddin SJ, Sjilpi JA, Alam SMS, Alamgir M, Rahman MT, Sarker SD 2005. Antidiarrhoeal activity of the methanol extract of the barks of Xylocarpus moluccensis in castor oil- and magnesium sulphateinduced diarrhoea models in mice. J Ethnopharmacol 101: 139-143.

Uddin SJ, Shilpi JA, Rouf R, Ferdous MM, Nahar L, Sarker SD 2007a. Neuropharmacological properties of Xylocarpus molucensis. Fitoterapia 78: 107-111.

Uddin SJ, Nahar L, Shilpi JA, Shoeb M, Borkowski T, Gibbons S, Middleton M, Byres M, Sarker SD 2007b. Gedunin, a limonoid from Xylocarpus granatum inhibits the growth of $\mathrm{CaCo} 2$ colon cancer cell line in vitro. Phytother Res 21: 757-761.

Uddin SJ, Shilpi JA, Byres M, Middleton M, Shoeb M, Nahar L, Sarker SD 2007c. Swarnalin and cis-swarnalin, two new tetrahydrofuran derivatives with free radical scavenging activity, from the aerial parts of Cuscuta reflexa. Nat Prod Res 21: 663-668.

Umachigi SP, Kumar GS, Jayaveera KN, Kishore DVK, AshokKumar CK, Dhanpal R 2007. Antimicrobial, wound healing and antioxidant activities of Anthocephalus cadamba, African Journal of Traditional, Complementary and Alternative Medicines 4: 481-487.

Watson WC, Gordon R 1962. Studies on the digestion absorption and metabolism of castol oil. Biochem Pharmacol 11: 229-236. 